\title{
The Concept of Inclusion in the Context of Sustainable Development
}

\section{Pojęcie inkluzji w kontekście zrównoważonego rozwoju}

\author{
Agnieszka Salamucha
}

\author{
University of Warsaw, Institute of Social Prevention and Resocialisation, \\ Podchorażych 20, 00-721 Warsaw, Poland \\ E-mail: a.salamucha@uw.edu.pl,ORCID:0000-0001-5320-0610
}

\begin{abstract}
The article presents a semantic analysis of the concept of inclusion, which - treated as the central category for Goal 16 of the 2030 Agenda for Sustainable Development (United Nations) - requires further definition. Initially, I outline the history and etymology of the word inclusion, provide various contexts of its use in Polish common language and in the academic area, take a closer look at the word family as well as synonyms and antonyms of the term inclusion (especially exclusion). Next, I explore functions of the concept of inclusion (descriptive, explanatory, normative) and problems regarding the concept. The conclusion contains four types of referents of the term inclusion.
\end{abstract}

Key words: inclusion, exclusion, concept, semantic analysis

\section{Streszczenie}

Przedmiotem artykułu jest pojęcie inkluzji, centralne dla celu 16 Agendy na Rzecz Zrównoważonego Rozwoju 2030 Organizacji Narodów Zjednoczonych. Termin inkluzja jest jednak wieloznaczny i jego znaczenie wymaga doprecyzowania. Przeprowadzam w tekście analizę semiotyczną tego terminu, poczynając od rysu historycznoetymologicznego, poprzez sposoby użycia terminu inkluzja w języku polskim i w różnych dziedzinach wiedzy, oraz przyglądam się rodzinie wyrazowej tego terminu, jego synonimom, bliskoznacznikom i antonimom, a wśród tych ostatnich przede wszystkim terminowi ekskluzja. Analizuję następnie funkcje pojęcia inkluzji (opisowo-wyjaśniającą i normatywną) oraz referuję spory wokół pojęcia inkluzji. W części końcowej proponuję typologię desygnatów terminu inkluzja.

Słowa kluczowe: inkluzja, ekskluzja, pojęcie, analiza semiotyczna

\section{Introduction}

The article presents a concept ${ }^{1}$ of inclusion referred to twice in the Goal 16 of the 2030 Agenda for Sustainable Development of the United Nations: for the first time in the phrase promote peaceful and inclusive societies, and then provide access to justice for all and build effective, accountable and inclusive institutions at all levels. This concept - next to peace and justice - seems to be the central category for understanding sustainable development in the context

\footnotetext{
${ }^{1}$ I use the word concept for the meaning of the term. Following the tradition of the Lublin school of methodology (Stanisław Kamiński, Andrzej Bronk, Stanisław Maj-
}

of social life, hence the need to provide a deeper insight into it appears entirely justified.

The concept of inclusion, highlighted nowadays in some social sciences (such as sociology, political sciences, special education, resocialisation and penitentiary science) as well as in public discourse (especially pertaining to minority groups and their relationship to the majority of the society) seems to be a self-explanatory notion, and its Latin origin suggests that it has most likely been known and applied for a long time. Yet the term inclusion appeared in the

dański). I make a distinction between a term/name (a parte linguae), a concept (a parte mentis) and a phenomenon/object (a parte rei). 
Polish literature as late as in the 1960s (earlier, in 1959, its antonym in French, l'exclusion, was used), and the concept of inclusion is only apparently selfexplanatory.

The term inclusion has become immensely popular and, surprisingly, it has behaved like certain plant species which conquered and colonised new territories, flourished there and replaced indigenous species over time. Inclusion is now mentioned everywhere: in official documents, political statements, in the mass media and in programs regulating the activities of various institutions. Forms of address in conversation or book illustrations can be inclusive (or non-inclusive). Moreover, the word inclusion seems to act as a magic wand - it is sufficient to touch a given object with it and it makes the object more beautiful, thanks to the powerful evaluative (positive) content of the word. Should one strive for inclusion? Apparently so (why?). Since the answer is yes, how to achieve inclusion?

Due to the significance of the phenomenon, it seems necessary to understand it better. One of the routes to better understanding is to look closely at the meaning of terms which define it; this is in line with the thesis that a language is a medium and the world of primary meanings is anchored in its memory (Martin Heidegger). This text aims to establish an initial semantic characteristic of the term inclusion in order to clarify its scope and content. Referring to etymology and archaic usage of the term in the Polish language, I present an overview of contemporary usage in various sciences and propose a typology of its meanings (referents), sharing some intuitions which may be useful in understanding the term within the context of resocialisation.

\section{2.}

There can be two approaches to the etymology of the term inclusion (in Polish inkluzja): a) since the term itself, just like its counterparts in Romance and Germanic languages ${ }^{2}$, originates from Latin, its IndoEuropean-Greek-Latin etymology can be pointed out; b) other linguistic intuitions are evoked if the Polish word wtaczenie is used (synonymous with inclusion but of different etymology).

a) The Greek word $\kappa \lambda$ cís is derived from the ProtoIndo-European kleh, which, according to Aleksander Brückner, means flexion, bend or, secondarily, an object with such properties (like a nail, a peg, a hook, a rod or a bolt), which may be used to close a door. Hence, the Latin name clavis and the Old Church Slavonic ключь signifying this object.

The Latin verb claudo has the same origin; it has many meanings such as I close (the noun clausum meaning closure comes from this); I conclude/I bring something to a close; I go (around) something;

\footnotetext{
2 E.g. English inclusion (appeared in literature around 1600 or even earlier ( $15^{\text {th }}$ century), in the sense of act of
}

I cut something off, I separate, I limit, I make something unavailable, I imprison (someone), I surround, besiege, block; or rhetorically: I round up.

The word inclusio, meaning closure (but also imprisonment, house arrest, as in Cicero's speech against Vatinius $(10,24)$ : Bibulum, cujus inclusione contentus non eras, interficere volueras), is a deverbative noun, derived from includo; it was created by adding a prefix in to claudo (I close). Includo has two main meanings: I close something in something else (I insert, embed, put something in something else, also in the sense I include something in something else) as well as I stop, I plug, I inhibit. It gives rise to two participles: inclusor (the one who besieges, imprisons, encircles) and inclusus (closed, imprisoned, tied, included, incorporated, but also aloof).

I note the first paradox of the term inclusion here: the word meaning containing has its roots in phrases referring to closing, in the sense of hampering the access, limiting, blocking, restricting, then imprisoning (these words have rather negative connotations) but also in protecting valuables against intruders (in medieval Latin there is the term inclusorium for a reliquary as a place to keep objects considered sacred).

Medieval Latin brought new meanings of the term inclusio, although these were based on the existing ones: from enclosing a territory (e.g. pasture) and cramming, condensing (compressio, densitas), to closing also figuratively (conclusio), connecting, linking (coniunctio), embodying, counting in (computatio, adnumeratio), to even assuming the existence of something (sumptio) or as a legal reservation, condition (exceptio, condicio). These meanings, less and less literal, more and more metaphorical, will be gradually applied and used in various fields of science, just like the adverb inclusively from the same semantic family, meaning together with, counting in, encompassing (includendo, computando, adnumerando), the adjective inclusivus, especially in the context related to logic: comprising, encompassing and the participle inclusus used in medieval logic and grammar to signify the implicit, not clearly stated, complicated, intricate.b) The Polish equivalent of inclusion, that is wtaczenie, is etymologically derived from the protoword tęk (English saddlebow; both the English and the Polish word refers to a horse saddle as well as a bow). If something is bowed, certain parts of the object are further away from each other, whereas others are closer: this ambiguity of meaning can be found in various terms with the same etymology. Originally the verbs derived from tęk - taczyć/tęczyć - meant to separate, to depart; then it started to mean just the opposite to combine, to unite. Interestingly, initial linguistic intuitions were preserved in the terms of opposite meaning, inclusion and exclusion, where it is the pre-

making a part of; since1839 also that which is included), French inclusion, Italian inclusione, Spanish inclusión. 
fix that determines their sense. The Slavic root klucz (key) appears in only one of the antonyms of inclusion, that is wykluczenie.

\section{3.}

In contemporary dictionaries of the Polish language the term inclusion (inkluzja) primarily refers to the activity of including something and to the result of that activity (what is included). Secondarily, it defines the relation between two sets, one of which is included in the other. The deverbative adjective inclusive has a slightly different meaning. It refers to something connecting or containing a certain whole, but also intended for everyone.

The Polish word wtaczenie, the closest in meaning to inclusion, can be understood in three ways: as adding a new member to the group (co-opting, enlisting, accepting, joining, recruiting, conscripting, involving), accepting someone to a group (incorporating, hiring, engaging) and as creating a whole with something or someone (annexation, joining, integration, incorporating, absorbing). In the semantic field of the term inclusion there are also categories of a group/subgroup, a system/subsystem and a set/subset.

If we analyse the meanings of the main antonym of inclusion, the term exclusion (ekskluzja), it may shed interesting light on our understanding of inclusion itself. The Latin root of exclusion is the same as that of inclusion - the prefix ex- lends it the opposite meaning though. Excludo means exclude, prevent; shut out, hinder; remove, separate; cut off, rule out (in the sense of cutting off and protecting at the same time; it also means hatch).

In contemporary Polish ruling out, separating, rejecting are defined as the obsolete meanings of exclusion, there is an emphasis on its logical connotations (exclusive disjunction) as well as social/sociological connotations (marginalisation, preventing from participation in social life; isolation from others). The adjective exclusive has also evolved to some extent: it signifies something separating itself from the environment, shutting out people who do not belong to a certain milieu, demanding exclusivity for itself; the additional meaning, which was added with a value-laden (positive? ambiguous?) undertone, was exclusive as limited to a closed group of people, luxurious, elegant, but also available only to a certain group (e.g. an exclusive interview).

The basic element of the term exclusion is counting out, understood as isolating (isolation, quarantine, separation, removing, disconnecting, seclusion, retreat, abandoning, alienation, loneliness, solitude, extracting, closing); eliminating unnecessary elements (choice, elimination, selection, sieve, removal, removing, option, disqualification); dividing into better and worse (selection, choice, screening, browsing through, segregation, selecting, sort, sorting, selecting, singling out); separating someone from someone else (isolation, separation, disconnecting, detachment, dissociation, removing, parting, confining); rejecting someone by a group (alienation/alienating, marginalisation, rejection, estrangement, elimination); shutting someone out from an activity (disqualifying, rejecting); undertaking an action that prevents something (avoiding, averting, precluding).

\section{4.}

It seems that at this stage of deliberations, when we talk about inclusion, we refer to spatial relations: something is inside and something else is outside; something is incorporated and something is rejected; something is surrounded, closed, and something remains outside of these confines. A given element can be a part of a certain whole as a result of a process (of becoming part) or it is not a part and it has never been, or it has been a part but due to another process it ceased to be a part of the whole. It is an interesting dialectic: inclusion as incorporating in a certain whole makes the object excluded (subject to exclusion) from another whole, and vice versa. Moreover, under certain circumstances, inclusion and exclusion are value-laden, when exclusion is tantamount to selecting elements which are assessed as more valuable and de facto it means including the said elements in the new whole (different to the pre-existing one). The status of the elements which are subject to inclusion is not determined: whether they maintain or lose their separateness; the latter would mean they melt away in the whole.

\section{5.}

The term inclusion is present in different fields of science, ranging from formal sciences (especially in set theory) to natural science, religious studies, humanities and social science.

In mathematics inclusion is a relation of including sets (perceived distributively). The set $\mathrm{A}$ is included in the set $\mathrm{B}$, or in other words: there is a relation of inclusion between set $\mathrm{A}$ and set $\mathrm{B}$, or: set $\mathrm{A}$ is a subset (part) of set $B$, when and only when every element of set $A$ is an element of set $B$, whereas set $B$ may include elements which do not belong to set $\mathrm{A}$ (not every element of set B must be an element of set A). If set A is included in set B and set B is included in set A, we have sets with equal scopes (MEL 1970, 242). This relation would be the supremum of inclusion: there is no longer a superior or subordinate set because all the elements of set $\mathrm{A}$ are at the same time the elements of set B.

In this context a complement of a set should be mentioned; the complement of a set $\mathrm{A}$ to a universe 1 is a set $\hat{A}$, including those and only those elements, which do not belong to the set $\mathrm{A}$. If we define a set of all people as a full set and a set of poets as set A, then the complement of set $\mathrm{A}$ will be the set of all 
the people who are not poets (MEL 1970, 243). In my opinion this has some intuitive implications for understanding inclusion in the social context. What is the supremum of inclusion: a relation of identity for two sets (all elements of set A belong to set B and vice versa), or a complement to a universe?

Basic intuitions connected with the terms inclusion and exclusion are also reflected in formal logic while characterising some truth-functional operators. Exclusive disjunction is a complex sentence with the either...or conjunction understood as exactly one of the two. This alternative is correct if one and only one of the clauses is correct. Inclusive disjunction is a complex sentence in which either or both of its clauses are true (negation of the conjunction: not true that both $\mathrm{p}$ and $\mathrm{q}$ ). The disjunction is false if both clauses are false.

In chemistry inclusion is understood as a process of retaining a crystal structure in empty spaces or closing the atoms, ions or molecules of a substance in the molecular cavities of another substance. Inclusive compounds result from this process; they are created when molecules of one substance (called a guest) are closed within the molecular cavities of molecular receptors or the empty spaces of a crystal structure of the other substance (called a host). Inclusive compounds may arise only when the size and shape of the guest's molecule are compatible with the size and shape of the molecular cavities or empty spaces in the host's crystal structure. There are no chemical bonds between molecules of both constituents, there are only weak intermolecular forces, which is why an inclusive compound can be easily decomposed into its constituents by dissolving in the right solvent or by heating. Therefore, inclusion cannot take place between any two substances, they have to be compatible in a way. The metaphor of a host and a guest is used here - one substance lets the other in, allows it to enter its territory. Moreover, inclusive compounds are not durable and are prone to disintegration.

In biology inclusion is like a cellular insert, called an inclusion body: it is a metabolically inactive (which means biologically dead) constituent of pro- and eukaryotic cells, which is a consequence of normal metabolic processes (e.g. the result of storing reserves or products of the metabolism, like drops of fat and glycogen in the liver and muscles, or crystals,

\footnotetext{
${ }^{3}$ The term inclusion is also used in taxonomy to describe a situation when two species, considered to be distinct, turn out to be the same (inclusion in such a sense appears more frequently in paleontology). In its adjecitve form, inclusive, it is used by William Donald Hamilton in his concept of inclusive fitness, which is one of the pillars of modern evolutionary biology.

${ }^{4}$ For instance, the pedagogy of religion refers to such an understanding of inclusion and exclusion, hidden in the concepts of inclusivism and exclusivism. What kind of religious education should be the subject of a dispute? The education that in uncertain (post)modernity will equip
}

pigments in skin and hair) or the result of degenerative changes or the changes connected with a disease or a viral infection. Inclusion is understood here as something comprised in something else - a product of other processes and in a way a foreign body to the cell, even though it is located inside the cell and does not do any harm to $\mathrm{it}^{3}$. So, there are two separate elements: the including and the included; what is superior and what is subordinate. The question is whether the included always remains separate within the whole or whether it - sooner or later - melts away, disappears, is absorbed by the superior whole. Inclusion is perceived similarly in mineralogy, where it is a synonym for a foreign body embedded in a mineral. As a rule these are fine crystals of various minerals which crystallised earlier than the host, droplets of enamel absorbed by a large crystal of another mineral, drops of water, grains of sand, etc. What also can be called inclusion is a fissility, crack or any other natural internal defect that disrupts the course of a beam of light in the mineral. The presence of inclusion in a gemstone can be perceived as something negative (as happens with diamonds) or positive (e.g. animal and plant remains embedded in amber, which is the only gemstone that can have organic inclusions). So, in this case it is ambiguous. The root of the word inclusion appears in the term inclusivism in religious sciences. It means a view voiced within one religious denomination, which states that salvation can also be achieved by followers of other religions (this view, just like exclusivism which states the opposite, is treated as part of the Christian discourse). More infrequently, inclusivism is defined as syncretism and the bringing together of opposing religious views. Inclusivism can take two different forms: the traditional one - where it is claimed that a chosen religion is the only true religion and believers of other denominations are not wrong only to the extent to which their opinions are consistent with the only true religion. In relativistic inclusivism it is claimed that all people have partial access to the absolute truth, and no denomination has a monopoly on the truth ${ }^{4}$.

\section{6.}

In humanities and social sciences the term inclusion with its antonym exclusion may take on different

people with reflection, knowledge, skills and competences connected with consolidating a local religious identity, acquiring apologetic tools and rather exclusive than inclusive thinking about one's own religious group? Or inclusive education, treating one's own view of reality as one of many possible views, but not the only one, respecting the differences and rights of others, non-believers included, to their own world view and way of life, opposing ideologisation of sacrum or any dominance and oppression, emphasising self-knowledge, critical reflection, emancipatory competences and social responsibility? (Humeniuk, Paszenda 2017, 11). 
meanings and perform various functions. Exclusion was used for the first time in the social context in Philibert Secrétan's article Sens et non-sens de la pauvreté, published in the Esprit magazine (1959). The text was about poverty and included the following sentence: C'est donc par l'exclusion que je tenterai de définir la pauvreté, par une exclusion qui atteint l'homme jusque dans ses moyens de subsistance, in which poverty is defined as exclusion/rejection afflicting a person in the context of their means of support. The article is actually not sociological, but rather philosophical and theological. The author formulates a thesis that all people, due to their sinfulness, experience poverty and exclusion (in a sense of their own accord, which is why it is more like self-exclusion), but thanks to God's forgiveness they attain inclusion, that is salvation.

The term exclusion - or perhaps the idea of exclusion? - appeared in René Lenoir's publication Les exclus: un français sur dix (1974). The phrase les exclus (the excluded) was applied to people who did not have the rights to social guarantees in France back then, so these were social groups identified on the basis of their place or lack thereof in the system of social insurance (Broda-Wysocki 2012, 53); physically and mentally disabled, elderly invalids, abused children, drug addicts, criminals, single parents, low-lives. Later it was also used to define the people whose qualifications did not match the demands of the labour market and immigrants; now the word excluded is used for groups burdened with social disapproval owing to their conflict with the law or due to their otherness in relation to the cultural code which is dominant in a society (Grotowska-Leder, Faliszek 2005, 10 and 26).

Since the mid-1990s the term exclusion replaced poverty and gradually became the key term in social and political programmes of the European Union, and now also in the United Nations. Why has this term become so attractive in a discourse of social sciences and public practice/public policies? Some researchers (J. Grotowska-Leder, P. Broda-Wysocki) point out that the new term shed a new light on phenomena which were actually quite well-known: poverty, unemployment, injustice and harm, slavery, exile, banishment, ghettoisation, excommunication, apostasy and other forms of rejection by the general public - it gave rise to studies from a new, fresh perspective. Its usage allowed the description and explanation of various phenomena, not researched so far; they all had a common denominator: being situated outside the dominant social mainstream. This was caused by the narrower content of the term $e x$ clusion as compared to poverty or unemployment: its content can be boiled down to excluding, being outside. If the content of the word is narrower, its scope gets broader (the word has more referents), so more objects - including the ones omitted so far, since they did not fit the previous conceptual framework - are incorporated in the scope. Thanks to such an approach, the scope of the explored phenomena gets broader and their new aspects come to the fore.

The application of the term exclusion allowed to study adequately the phenomena of being outside, which were not connected (at least not directly) with poverty, unemployment, lack of social guarantees, addiction to psychoactive substances, etc. An example of such exclusion is the exclusion connected with one's level of consumer competence: what someone can afford defines their status in a social hierarchy and their overall life project (products from high-end brands, private education, etc.) People can be thus excluded even if they have sufficient financial means, but have decided not to participate in the race of consumerism. One can be also excluded on moral grounds (Broda-Wysocki, 2012).

With such a broad definition, the term exclusion is not distinctive (it is impossible to distinguish which object belongs to its scope and which does not), so it is difficult to come up with an adequate definition of the term (a nominal definition) or a definition of the phenomenon itself (a real definition). This may pose problems in conducting empirical studies on the phenomenon of exclusion (we are not sure what we are really studying), especially in measuring its scale and even more in organising actions and addressing specific help.

The words close in meaning - in some contexts treated like synonyms - to the term exclusion are banishment, marginality/marginalisation, isolation, rejection (Faliszek 2005, 45). The term exclusion is not associated with any new intuitions (in general it is identified as a problem with functioning and participating in the life of a given community according to the standards considered »normal « by the said community (Broda-Wysocki 2012, 12)) - as opposed to the concept of marginalisation. It suggests the image of a book: there is the main part of the page that attracts the most attention and there is a margin - be it narrower or broader, but frequently disregarded. The terms marginal/margin appeared in the French language at the beginning of the 1970s, describing the young people participating in the protests of 1968 , that is people who made a voluntary decision to be on the margins: they left the centre of the society, that is the mainstream of its life, but they remained its members at the same time (BrodaWysocki 2012, 29). In time these terms were applied to other phenomena - of a different origin and structure - and the common denominator for them was being on the fringe. For instance, in South America they were used to depict inhabitants of favelas, who moved from villages to cities and became the majority there, yet did not choose their social position, did not belong to a formal economic system nor to any groups shaping the mainstream economy or culture. The term inclusion appears here to describe a certain antidote (or perhaps a panacea?) to (ubiquitous) ex- 
clusion. P. Broda-Wysocki (2012, 29 and 144) compares it to the Trojan horse by means of which politicians try to refresh the discourse on social issues which they were not able to solve properly, a discourse that turns out to be useful when they try to get rid of an unfavourable social phenomenon.

The content of the term inclusion is actually quite narrow - it comprises the basic intuition of encompassing, being (for the first time? once again?) on the inside. As one can easily note, different notions/concepts/theories of inclusion are determined by the earlier notions/concepts/theories of exclusion. And because exclusion and inclusion pertain to basic aspects of the functioning of individuals and groups in society: their cultural rootedness, participation and access to important goods and social resources (Grotowska-Leder, Faliszek 2005, 9), we are faced with a multitude of concepts of exclusion and inclusion, situated additionally in theories both sociological and those related to the political science of society and the relationship between society and the individual. The particulars of the theories combined with the social situation in illo tempore make our understanding of exclusion and inclusion more specific, which is already conspicuous at the level of a definition ${ }^{5}$.

I mention different definitions of inclusion (source: P. Broda-Wysocki (2012, 66, 71 and 139): a) integration of people or groups into the structures of the market and/or the state while maintaining their previous inequalities; b) adequate access to resources and equal access to participation in individual and collective life opportunities; c) a possibility to pursue a good life; d) participation in social relations (being a member of a community, with a number of rights and obligations ensuing from this); e) combating exclusion. The definitions show what is perceived as valuable in an individual-society relationship; as to their wording, they include terms potentially synonymous or belonging to the same semantic family as the term inclusion, while also carrying their own meanings: integration, participation and partnership (Faliszek 2005, 45; Broda-Wysocki 2012, 179).

A certain ideal of social life is also presented in the catalogues of goals of inclusion: they mention social cohesion, equality, prosperity, providing the necessary financial means for life, restoring dignity of the excluded, creating and providing equal opportunities, equal rights, fighting discrimination; there is even inclusion as its own goal. A different approach

\footnotetext{
${ }^{5}$ This is how P. Broda-Wysocki $(2012,12-13)$ describes a process of creating definitions of exclusion and inclusion: noticing the phenomenon of exclusion (...) creating a definition of the observed phenomenon of exclusion, programming inclusive activities - as far as possible, not necessarily in direct response to the observed and defined phenomena of exclusion (...) deriving a definition of inclusion from a possibility of inclusive activities (...). Definitions of exclusion (if they are not created to match specific activi-
}

to the goal - defined as something to be achieved by inclusion - is an inclusive society, which is the opposite of an exclusive society. There is no common opinion as to the meaning of the term, and the priorities of such a society are not defined either; usually general statements have to suffice, referring to the idea of participatory citizenship, but also social justice and diversity understood in an egalitarian way; sometimes inclusive democracy is mentioned (Broda-Wysocki 2012, 64, 68, 175 and 212). And just as with exclusion, we have a term which is neither distinctive (one cannot unambiguously distinguish which object belongs to its scope and which does not), nor operative, which makes it rather difficult to study the phenomenon of inclusion and projects of inclusive action. If we decide that, for instance, prosperity is the goal of inclusion (or appropriate social position or a subjective treatment), it is still unknown what level would be just, adequate or satisfactory enough to decide that inclusion has been reached.

I am willing to agree with Krzysztof Frysztacki (2005, 19), who states that "whatever is said about inclusion, it is (...) in its various options first and foremost a certain worldview and a theoretical and ideological structure ensuing from it: it is an attempt to construct a desired image of the social world, of something better than what was known so far, worthy of various endeavours or even serious costs if they need to be incurred. It should be emphasized that the majority of researchers of social life are aware that the concept of inclusion is closely connected with idealisation: this is why it plays a function parallel to idealisations applied in natural sciences. Its utopian nature is highlighted to avoid the risk of undertaking inefficient action on an excessive scale: it is necessary to modify expectations as to their results (...): one should be content with success understood 'as engaging the marginalised people in the principles and rhythm of an organised human activity and/or rooting them in an intermediary structure between them and an open society' (K. Frieske, source: Faliszek 2005, 49).

What is interesting is the use of the term universalisation in this context, or the use of other words from the same semantic family: the concept of inclusion is probably connected with the theory and practice of generalisation, universalisation, creating certain holistic variants of social life, overcoming what is socially discriminative, or contrary, and as a result - segregating; what is universalising and inclusive

ties) are usually relative and are related to specific phenomena observed by researchers. Typically, they are rooted in the social reality yet have no universal features, therefore they are so numerous and become outdated very fast. Definitions of inclusion, on the other hand, are rooted in possibilities of activities planned on a bureaucratic level (be it public - the state or social-local governments and social organisations using public means), therefore their ad hoc nature or instrumentalism. 
is perceived as 'good', fair, useful, hence worthy of certain endeavours in order to attain such a state of affairs (Frysztacki 2005, 18).

Equating inclusion with universalisation brings to mind - not in the strict sense, but analogically - the definition of inclusion as a relation between sets. Perhaps universalisation pertains to the fact that two sets will be identical in their scope (so a certain peak of inclusion will be achieved). Maybe it is the relation of complement to a universe. Or perhaps it is difficult to apply categories from set calculus because it is not about the sets in a distributive sense, but in a collective sense (the elements are not understood as homogeneous entities but as aggregates/conglomerates of features/elements).

\section{7.}

The term inclusion is sometimes replaced with the phrase inclusive actions. In this context inclusive challenges and inclusive projects may occur as (proposed) goals of inclusion when it is defined as an action (Broda-Wysocki 2012, 65 and 223); strategies of inclusion with measures such as inclusive language $^{6}$ and inclusive communication ${ }^{7}$ - when inclusion is defined as a method. On the other hand, inclusion itself appears with various specifying phrases, for instance: social inclusion, political inclusion, inclusion in education (other expressions focus on inclusion as the goal of an activity: inclusive teaching, inclusive education). In a similar vein, social exclusion or legal exclusion are discussed.

The terms exclusion and inclusion (antagonistic towards each other) and their synonyms provide attractive wording, used in the titles of conferences and academic papers, suggesting a multitude of presented positions and the topicality of a subject under discussion - whatever it may be. It is quite typical in pedagogy - perhaps more frequent than in other disciplines, but also in social work, the sociology of medicine, even in cultural studies and literary theory. There is a discernible trend: these two terms are used in literally every context that allows for it.

\footnotetext{
${ }^{6}$ In Polish the term is a word-for-word translation of inclusive language. According to the Collins Online Dictionary it is a language that avoids the use of certain expressions or words that might be considered to exclude particular groups of people, esp. gender-specific words, such as 'man', 'mankind', and masculine pronouns, the use of which might be considered to exclude women. The relevant document of the General Secretariat of the Council of the European Union of 2018 (2019, 7) defines inclusive language thus: inclusive, bias-free language avoids stereotypes and references to irrelevant details. It acknowledges positive qualities in people of all genders
}

8.

In order to present the ambiguity of the concept of inclusion, I would like to discuss several problems related to it.

a) The first area of discussion pertains to the attribution of a certain value to the phenomena - inclusion is presented as something positive, whereas exclusion as something negative. The more exclusion is perceived as something negative, the more inclusion becomes good and necessary; the ideas of inclusion evoke half-intuitive sympathy (Frysztacki 2005, 19 and 23); exclusion is misery, inclusion is happiness (P. Declerk, source: Broda-Wysocki 2012, 53). Yet, provocatively, one may reverse this equation.

Starting from a general level, it is exclusion that can be treated as a natural and elemental phenomenon: in the social world, what takes a distinguishing or even excluding form, may be treated as a manifestation of some real, unavoidable, influential processes and phenomena (Frysztacki 2005, 19), and inclusion has an artificial, imposed character. Theoretical assumptions concerning the essence of social life may also be significant: from the perspective of structural orientation, diversity may become a source of social problems; from the perspective of the concept of deviation, (...) the dominant unifying tendencies and the lack (...) of space for diversity may make otherness and nonconformity unacceptable and consequently problematic (Frysztacki 2005, 23).

At the level of individual social phenomena, the dialectic exclusion-inclusion may also be reversed. The groups of the excluded, due to their exclusion, may avoid some other forms of oppression from society, oppression more dangerous than what they experienced so far. Moreover, inclusion undertaken in one aspect may lead to unfavourable consequences in another aspect, e.g. inclusion understood as integration is harmful to immigrants because it leads to assimilation and the loss of their cultural resources. The very fact of belonging to a group of people who are subject to inclusion may make a person susceptible to exclusion in other fields, to passivity (it is difficult to act together without a sense of common identity, and then - no-one is proud of being excluded) and to a constant sense of being insufficiently respected, or even to stigmatisation (Marek Rymsza's thesis), whereas groups of the excluded from a certain sphere

and sexual orientations, persons with disabilities, people of all ages, from all backgrounds and of any or no religion or belief.

7 The same document, in order to explain inclusive communication, introduces a few directives specifying how to communicate in an inclusive way: If you - even unintentionally - use inappropriate expressions or biased language, you exclude people and thereby create barriers to communication. To make the language you use bias-free, avoid expressions that demean or exclude people because of age, gender, sexual orientation, race, religious or other beliefs, ethnicity, social class, or physical or mental traits. 
may create an alternative culture and develop a strategy of everyday resistance, integrating with each other within a niche which is conducive to their functioning.

b) Another strand of the discussion focuses on the adequacy of the category of exclusion and inclusion to describe and explain social phenomena. When the exclusive-inclusive paradigm is questioned, it is based on the following observation: the division into exclusive and inclusive is just arbitrary; what is more, every inclusion contains, metaphorically speaking, seeds of exclusion (and the other way round). The point is that exclusion and inclusion may take place at the same time within a single society, pertaining to different groups. Every culture has great inclusive potential (for its representatives) as well as exclusive potential (for all the others). Inclusive activities themselves may embrace exclusive elements (e.g. paternalism). Exclusion seems to be an unavoidable side effect - or perhaps an immanent element - of social systems which aim at achieving inclusion, and inclusion understood as cohesion would have a very great exclusive potential (the groups which excluded all 'the others' may seem the most cohesive) (Broda-Wysocki 2012, 242).

c) The third, most hotly debated area of the discussion focuses strictly on inclusion as actions / strategies, because it deals with their efficiency. I do not have sufficient expert knowledge to present and assess various positions in the debate about the efficiency of inclusive actions. Let me just say that the efficiency of inclusion is gradable (for instance, incomplete inclusion, partial inclusion and unsatisfactory inclusion are mentioned), and inclusive actions may be undertaken by various entities; then the fact who the agent of this inclusion is (a state, social organisations, enterprises, etc.) may be decisive for their efficiency (Broda-Wysocki 2012, 23, 175 and $195)$. The tone of the discussion is usually pessimistic: one can sense an awareness of discord between a noble discourse about inclusion and the nature of actions that were finally accepted - in practice it is difficult to translate ideals into specific actions.

\section{9.}

Theoretical and practical problems with the concept of inclusion ultimately have their source in social human nature (homo animal sociale). Exclusion as a phenomenon has always existed and will exist for ever - just like inclusion. Belonging to a social group is something primary, in a way decisive for an individual's identity. Thanks to other people a little person enters the world of culture, absorbs a certain hierarchy of values, finds his or her place in society. Moving between different groups / structures, even though possible to some extent, has its limitations: family, cultural, political, economic, religious, sometimes moral ones. As long as people differ be- tween one another in any respect, they will be situated differently in society due to these differences. This concerns everyone who belongs (or who does not belong) to a given community and influences the rights that they have in the community and the consequences of these differences.

Additionally, deliberations about inclusion and exclusion have an axiological background. If someone should be included in a group, then who? For what reason? On what grounds? Are there any indications or contraindications for including $\mathrm{x}$ rather than $\mathrm{y}$ ? A pragmatic justification is not sufficient here: values are indispensable in order to provide a mandate for initiating and conducting actions which will aim at making a change, both on a social and individual scale, for the person involved in inclusion. But what does it mean to share common values in an axiologically varied society?

On the other hand, academics agree that some social phenomena defined as exclusion are just wrong and need to be eradicated, without a necessary reference to the considerations about the nature of good and evil, without any ethical justifications for certain actions. There are exclusive phenomena which cannot be and should not be ignored, and they cannot be underestimated by saying that they are just natural, inevitable and perhaps even beneficial in the long run (...) Some manifestations of poverty (...) may and should raise concern. As a result, the variants of social policy, theoretically informed and justified, which are to prevent these phenomena and modify their severe consequences, are feasible (Frysztacki 2005, 21).

In this context I would like to mention the conflict between an individualist and collectivist approach, regarding the relation between a person/an individual and society. In places where the emphasis is placed on a person's right to be himself or herself, to enjoy personal freedom, to pursue one's own ambitions (...) [then] the circumstances that disturb these rights and opportunities for individuals or possibly small groups, are perceived as problems, whereas collectivist orientation places far more emphasis on the collective, on the superior value of a community, on the need to subordinate individuals to what defines and protects social entities (Frysztacki 2005, 23). For representatives of the extreme individualist approach, inclusion would be desired only when a person himself or herself wants to be included in a group, in a way in their own right; for representatives of the extreme collectivist approach, even enforced inclusion is a positive phenomenon for the whole society. Between the two extreme approaches there is an entire rich continuum of moderate positions, with plenty of nuances.

\section{Conclusions}

In order to summarise the considerations presented so far, I suggest the following typology of meanings 
(typology of referents) of the term inclusion; each of them accompanied by some remarks, more heuristic than systematising.

a) inclusion as an activity/action

It seems that inclusion is not a spontaneous process in the social world; in a way it must be provoked externally and its course must be controlled and corrected.

Perhaps the praxeological toolbox introduced by N. Rescher $(1966,215)$ could be useful in analysing inclusion as an action: (1) agent (who did the activity?), (2) kind of action (what did he do?), (3) modality of action (how did he do it?): (a) modality of manner (in what manner did he do it?), (b) modality of means (by what means did he do it?), (4) setting of action (in what context did he do it?): (a) temporal aspect (when did he do it?), (b) spatial aspect (where did he do it?), (c) circumstantial aspect (under what circumstances did he do it?), (5) rationale of action (why did he do it?): (a) causality (what caused him to do it?), (b) finality (with what aim did he do it?), (c) intentionality (in what state of mind did he do?). Yet such an analysis would require a separate study. b) inclusion as a product/result of an action I make a distinction between a goal (at the starting point) and a result (at the endpoint), because, undeniably, not every plan is fully implemented. Moreover, it is a paradox of praxeology that a person is never aware of all the consequences of their action because, among other things, the action frequently has side effects that the agent is not able to foresee (Pszczołowski 1982, 28 and 173).

Inclusion as a result may be quite ambiguous: it may be the result of a non-inclusive action (even exclusion), and inclusion as an action may lead to a result other than inclusion. A question arises: to what extent is inclusion as a result similar to inclusion in a mineral - a foreign body from the perspective of the whole, and to what extent is a kind of incorporation taking place?

c) inclusion as a relation

The word inclusion may be used to describe the very relation between two sets - in a collective sense (an aggregate of elements) or in a distributive sense (a set of objects with a common feature). For instance, such a relation may take place between an excluded group and the entire society or between the excluded and the excluding. Once again, an issue of the supremum of inclusion comes into play: is it a relation of identity for two sets when all the elements of set A belong to set $\mathrm{B}$ and vice versa? Or is it perhaps a complement to a universe?

d) inclusion as an idea

This is the result of idealisation which is about amplifying certain features in order to create a name (and a concept) of an object which fully possesses these features. Hence, inclusion in this context does not refer directly to actual actions, their products and relations, but it is a leading idea, a motto on the banner. It seems that this meaning of the term inclusion is the dominant one in the context of sustainable development. In this sense inclusion always remains unattainable in the real world; it is a postulated, desired, yet unreachable goal of various endeavours.

\section{References}

1. BRODA-WYSOCKI P., 2012, Wykluczenie i inkluzja społeczna. Paradygmaty i próby definicji, Instytut Pracy i Spraw Socjalnych, Warszawa.

2. BRÜCKNER A., 1927, Stownik etymologiczny języka polskiego, Krakowska Spółka Wydawnicza, Kraków.

3. Collins Online Dictionary, www.collinsdictionary.com (29.12.2019)

4. Elektroniczny Słownik Łaciny Średniowiecznej w Polsce, scriptores.pl/elexicon/pl (29.12.2019)

5. Encyklopedia PWN, encyklopedia.pwn.pl (18.11.2019)

6. FALISZEK K., 2005, Ekskluzja i inkluzja - dwie strony tego samego problemu?, Ekskluzja $i$ inkluzja społeczna. Diagnoza - uwarunkowania - kierunki działań, ed. Grotowska-Leder J., Faliszek K., Wydawnictwo Edukacyjne Akapit, Toruń, p. 45-50.

7. FRYSZTACKI K., 2005, Wokół istoty „,społecznego wykluczania” oraz 'społecznego włączania', Ekskluzja i inkluzja społeczna. Diagnoza - uwarunkowania - kierunki działań, ed. Grotowska-Leder J., Faliszek K., Wydawnictwo Edukacyjne Akapit, Toruń, p. 1724.

8. General Secretariat of the Council of the European Union, 2018, Inclusive Communication, https://www.consilium.europa.eu/media/35446/en_ brochure-inclusive-communication-in-the-gsc.pdf (20.03.2021).

9. GROTOWSKA-LEDER J., Eksluzja społeczna aspekty teoretyczne i metodologiczne, Ekskluzja $i$ inkluzja społeczna. Diagnoza - uwarunkowania - kierunki działań, ed. Grotowska-Leder J., Faliszek K., Wydawnictwo Edukacyjne Akapit, Toruń, p. 25-44.

10. HUMENIUK M., PASZENDA I. (eds.), 2017, Między ekskluzja a inkluzją w edukacji religijnej, Instytut Pedagogiki Uniwersytetu Wrocławskiego, Wrocław.

11. Internetowy Stownik Synonimów Języka Polskiego Online, 2019, synonim.net (29.12.2019).

12. KUMANIECKI K., 1957, Stownik tacińsko-polski, PWN, Warszawa.

13. MARCISZEWSKI W. (ed.), Mała Encyklopedia Logiki, 1970, Ossolineum (skrót MEL).

14. Online Etymology Dictionary, 2019, www.etymonline.com (29.12.2019).

15. PSZCZOŁOWSKI T., 1982, Zasady sprawnego dziatania. Wstęp do prakseologii, Wiedza Powszechna, Warszawa.

16. RESCHER N., 1966, Appendix II (Aspects of Action), The Logic of Decision and Action, ed. Rescher N., University of Pittsburgh Press, p. 215-219.

17. SECRÉTAN P., 1959, Sens et non-sens de la pauvreté, Esprit, 273: 715-726, esprit.presse.fr/article/sens-et-non-sens-de-la-pauvrete-24185 (11.01.2020).

18. Słownik Języka Polskiego PWN, sjp.pwn.pl (18.11.2019).

19. UN, Sustainable Development Goals, https:// sdgs.un.org/goals/goal16

(20.03.2021). 